\title{
Activism and Civil Society: Broadening Participation and Deepening Democracy
}

\author{
PAUL DEKKER and RAMÓN A. FEENSTRA*
}

Tilburg University and The Netherlands Institute for Social Research / Universitat Jaume I

In recent years, we have witnessed the emergence of political activism through an irruption of citizen movements $-5 \mathrm{M}$ or Occupy-, the birth of new political platforms -5 Stelle, Zyrisa, Podemos- and the rise of new direct action groups, such as Anonymous, Stop-Evictions Movements, cooperatives, to name just a few. In some countries this activism has not just placed substantial pressure on traditional actors of representative democracy and governments, but has also opened up opportunities for structural changes in the policymaking context and procedures (García Marzá, 2012). At the same time, the emergence of new forms of citizen political involvement influences our classical understanding of the political participation concept. In political science, the term participation is generally, and sometimes exclusively, associated with representational structures of government (Verba and Nie, 1972). Currently, numerous examples demonstrate that participation is not limited to either choosing through elections those who form and control the government, or trying to influence their decisions. Participation transcends the act of voting, becoming a party affiliate or contacting political representatives; that is, it takes multiple, new, and both conventional and unconventional shapes, in both political and civil-society circles.

The background of the present rise of political discontent and protest in Europe is the financial economic crisis since 2008 in general, and the Euro Crisis in Southern Europe in particular. Three articles in this special issue focus on Southern Europe. In order to reflect about how different developments have been, we present a few graphs of developments in Spain, Greece (the two countries dealt with in this issue), and also Portugal, Germany and Sweden, for a comparative perspective. Figure 1 shows the development of (net) trust in parliament. It reveals very different developments, from stable or even somewhat increasing positive trust levels in Sweden and Germany,

* Ramón Feenstra is a member of research projects: FI2013-47136-C2-2-P, funded by the Spanish Ministry of Economy and Competitiveness, and P1.1B2013-24, funded by the Universitat Jaume I of Castellón. 
to enormous falls in the South. For instance, Spain goes from +19 points at the beginning of 2008 (54\% tended to trust, 35\% tended not to trust parliament) to $-74 \%$ points at the end of 2014 (10\% tended to trust, $80 \%$ tended not to trust).

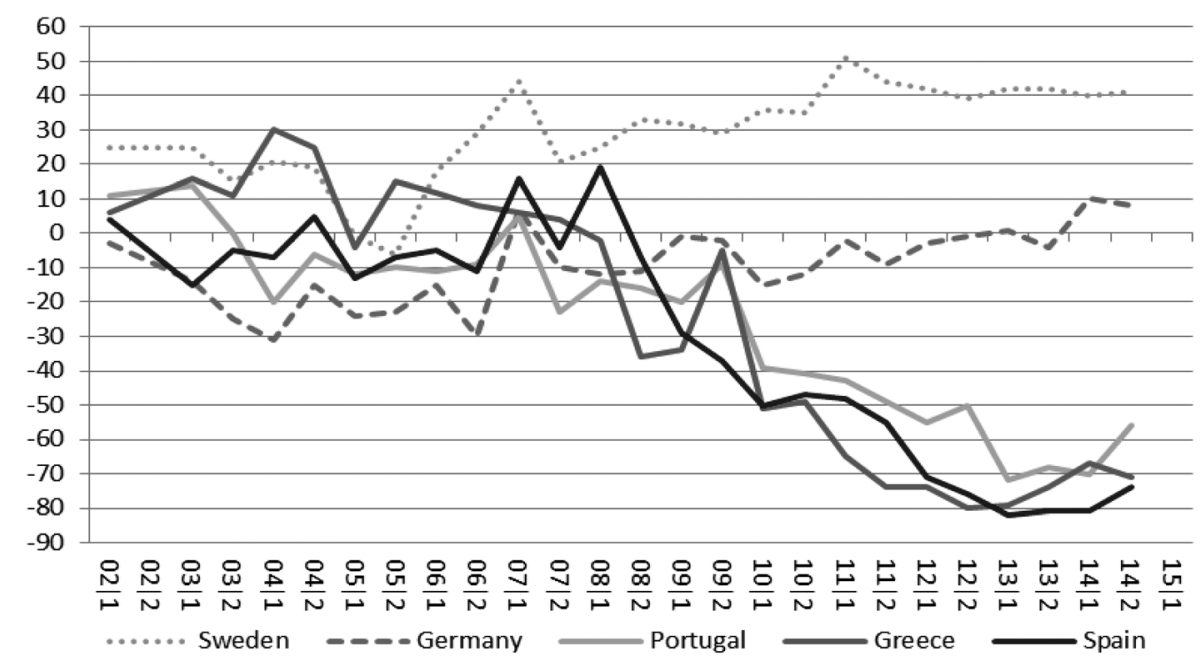

* Presented is the percentage of people who 'tended to trust' minus the percentage who 'tended not to trust' (the lower house of) the National Parliament.

Source: Eurobarometer 57.1 - 82.3

Figure 1

Net Trust in National Parliaments, ${ }^{*} 2002-2014$

Figure 2 shows high, and maybe even rising, levels of satisfaction with the functioning of national democracy in Sweden and Germany, a lower, but not deteriorating, level in Portugal, and a clear decrease in Spain and Greece (no 2012/13 data). 


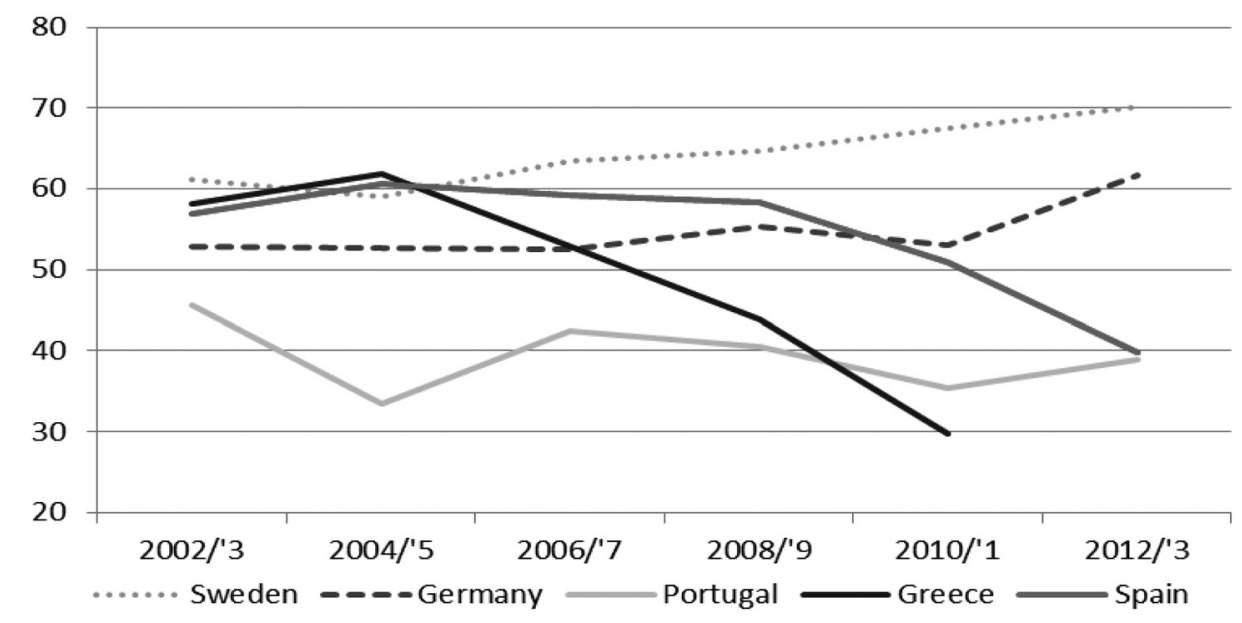

* Average satisfaction with 'the way democracy works in [country]' on a scale from 0 (extremely dissatisfied) to 100 (extremely satisfied)

Source: European Social Survey 1-6

Figure 2

Satisfaction with Democracy,* 2002-2013

Figure 3 reports participation in demonstrations, with rather stable, but low levels of not more than $10 \%$ of the population pretending to have taken part in demonstrations in the 12 months before the interview, where Spain had overall higher levels and over 30\% in 2004. That year Spain suffered the 11 March bomb attacks and Aznar's government's information manipulation about those responsible for the attacks. During the same period, there was a change of government with PSOEs' electoral victory.

The 'lawful public demonstrations' of Figure 3 are only one manifestation of political protest (as we may generally assume in eu countries. Yet in North Korea, not joining a demonstration to show support for the Leader might be quite a courageous form of protest). Countries have different repertoires, which might change over time (Quaranta, 2012), just as organising social movements might do, or copying forms of action of movements elsewhere (della Porta and Mattoni, 2015). 


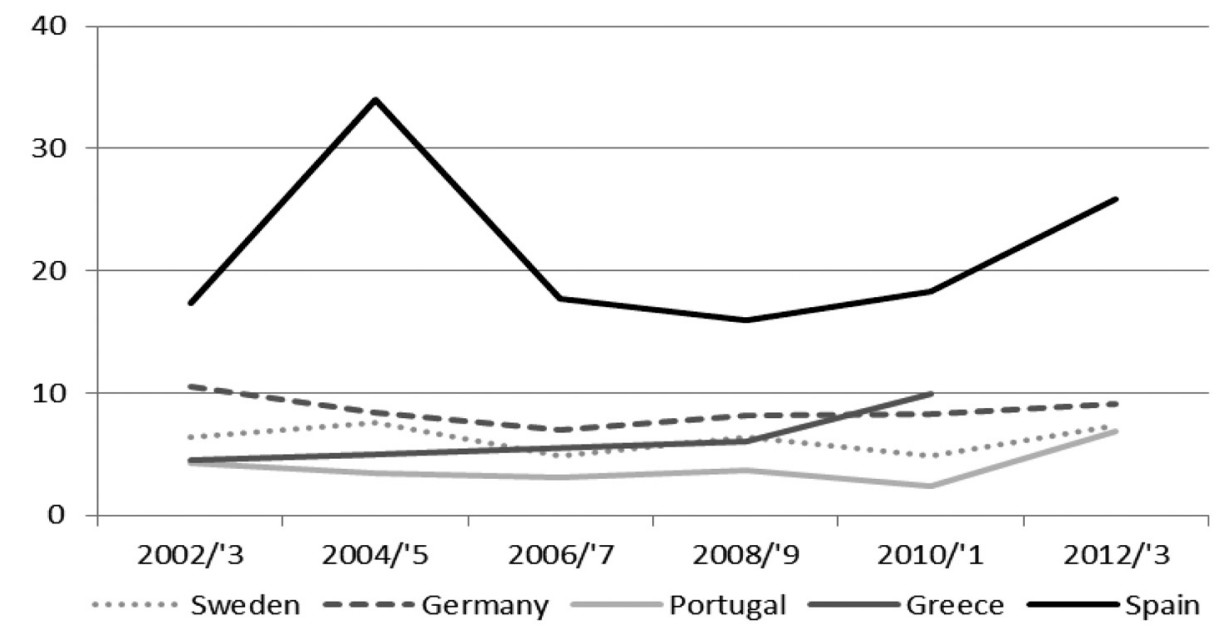

* \% that has taken part in a lawful public demonstration during the last 12 months to try "to improve things in [country] or help prevent things from going wrong".

Source: European Social Survey 1-6

Figure 3

Participation in demonstrations, $* 2002-2013$

Diverse democratic systems seem to have witnessed the establishment of two key trends. On the one hand, there is growing disaffection with representation structures caused by generalised disapproval of how institutions have functioned, although the value of their existence is never denied. On the other hand, there is growing demand for civic participation among various population strata.

The new ways of action, in turn, renew and transform forms of political participation of civil society, which finds fresh alternatives, perspectives, tactics and repertoires surface around the notion of protest, activism and civil society (van Laer and van Aelst, 2010). This special issue of RECERCA includes a multidisciplinary range of articles that have one thing in common: the analysis of the meaning and dynamics of this civil society political participation renewal and reconfiguration. Previous issues of RECERCA have focussed on the meaning of civil society (Dekker, 2008; Feenstra, 2008), the importance of the common goods (Abad and Abad, 2014), or the role of social economy as an economic engine (Herrero-Blasco, 2014; Donati and Calvo, 2014; Innerarity, 2012; Ordóñez, 2014).This special 2015 issue focuses 
on the field of activism and its role in reshaping the meaning of participation, and includes five articles of authors affiliated to institutions in five countries: Mexico, Denmark, Ireland, Spain and Australia.

In the first article, «The Psych-politics of Austerity; democracy, sovereignty and civic protest», Powell argues that new forms of civic protest are giving voice to people in the age of the Internet. The author poses the question of whether these new ways of anti-austerity protests form part of: (a) a long militant, and sometimes violent tradition of street politics based on class struggle or; (b) a process of deepening democracy into more participatory forms for peaceful and creative political interaction and democratic decision making. Powell considers that movements such as Occupy form part of an anti-austerity counter-fiction that is creating a participative democratic narrative in which citizens are being invited to become actors in making their own history. The author concludes by asserting that we are experiencing «the democratisation of democracy in response to the invisibility of autocratic power that seeks to discursively mould contemporary political reality, and fails».

In the next three articles, we focus on experiences in Southern Europe. In «Europeanization and social movement mobilization during the European sovereign debt crisis: The cases of Spain and Greece», Bourne and Chatzopoulou examine the Europeanisation of social movements in the European Sovereign Debt (ESD) Crisis context. These authors present the findings of a pilot study which centers on social movement mobilisation in Spain and Greece between May and June 2011. Using newspapers as a primary source of data, the authors suggest that the largest category of contentious-action events in both Spain and Greece was action that focused entirely on the domestic arena during the studied period.

The third article, «Emotional politics on Facebook. An exploratory study of Podemos' discourse during the European election campaign 2014», focuses on the new Spanish party Podemos. Following a pragmatic linguistic approach, Sampietro and Valera analyse the presence of positive Facebook messages during the campaign and the contrast of these messages with other public discourses of this political formation. The authors show a significant presence of emotions in Podemos' discourse

As the fourth article, González' text «Squatting movement and housing movement: similarities, differences and convergences in times of crisis» goes more deeply into another key Spanish political actor: the squatters' movement and the Platform of by Mortgage Victims (PAH, in Spanish). This text compares these two actors and their different political courses, repertories, demands and strategies. González goes into the meaning and importance of 
some of the actors who have played a more relevant role in the vibrant civil society of Spain in recent years.

Fifth and finally, in «Democracy will never be the same again: $21^{\text {st }}$ Century protest and the transformation of politics», Tormey looks at the current wave of protests and demonstrations against austerity in favour of democracy and asks what they have in common and what is new. He concludes that «the revolts and rebellions that we see around Europe, and indeed the world, have in common their rejection of the logic of representative politics and representation more generally». This author analyses what he states as a crisis of representative politics, a crisis which is transforming the nature of mobilisation, contestation and politics more generally. More specifically, Tormey considers that "Politics is undergoing a Gestalt shift», on which we need to reflect as political theorists and empirical scientists.

Thus the country case studies and general reflections of this special issue highlight important aspects and profound layers of today's movements against austerity and for democracy in the Western world, particularly in Southern Europe. We hope that the questions raised may contribute to agenda-setting for democratic renewal as well as for civil society research, even if the specific protest phenomena, movements and organisations examined herein might well disappear or evaporate.

\section{REFERENCES}

ABAD, J. \& M. ABAD (2014): «La economía social y solidaria como alternativa económica. Bienes comunes y democracia», Recerca. Revista de Pensament $i$ Anàlisi, 15, pp. 55-75.

Alonso, S. (2014): «Votas pero no eliges: la democracia y la crisis de la deuda soberana en la eurozona», Recerca. Revista de Pensament i Anàlisi, 15, pp. 21-53.

DekKer, P. (2008): «La disolución de la sociedad civil: sobre los ideales y las vaguedades en la esfera de las asociaciones de voluntariado», Recerca. Revista de Pensament i Anàlisi, 8, pp. 113-133.

Della Porta, D. and A. Mattoni (eds.) (2015): Spreading protest. Social movements in times of crisis, Colchester, ECPR Press.

Donati, P. \& Calvo, P. (2014): «New Insights into Relational Goods». Recerca. Revista de Pensament $i$ Anàlisi, 14, pp. 7-17.

FEENSTRA, R. (2008): «Diferentes concepciones de sociedad civil:la problemática de un concepto", Recerca. Revista de Pensament $i$ Anàlisi, 8, pp. 47-66. 
García Marza, D. (2013): «Democracia de doble vía: el no-lugar de la empresa en la sociedad civil», Revista del Clad. Reforma y Democracia, 57, 67-92.

InNerarity, D. (2012): «Otra ciencia económica», Recerca. Revista de Pensament $i$ Anàlisi, 12 , pp. 53-59

Herrero-Blasco, A. (2014): «La Economía Social: su función económica y las políticas públicas de fomento", Recerca. Revista de Pensament i Anàlisi, 15, pp. 77-91.

ORDOÑEZ, V. (2014): «Economía, valores y democracia. Diálogo con Christian Felber», Recerca. Revista de pensament $i$ anàlisi, 15, pp. 153-161.

QuARANTA, M. (2012): «Measuring political protest in Western Europe: assessing cross-national equivalence», European Political Science Review, 5(3), pp. 457-482.

Van Laer, J. and Van Aelst, P. (2010): «Internet and social movement action repertoires: Opportunities and limitations", Information Communication and Society, 13(8), pp. 1146-1171.

Verba, S. and Nie, N. (1972): Participation in America: Political democracy and social equality, Nueva York, Harper and Row. 